so systematic, the manner of publication of its techniques and results is so unusual, and so few people in the West can read scientific Russian or have access to publications, that the need for a book of this type is very acute. Therefore, the appearance of this book is to be warmly welcomed. No doubt it will deservedly find its way to libraries and to the private homes of those interested in aerophysics, astrophysics, space biomedicine, energymatter processes, aerospace science and engineering, and relevant fields.

In spite of its shortcomings (incoherent statements in different parts, an almost complete absence of references to professional aerospace journals and magazines, erroneous spelling, and the like) the authors have succeeded in condensing the vast but scattered information into a regular set of well illustrated and quite readable parts and chapters. It can, in any case, be said that this is the first reference book of its kind, although, understandably, it could not embrace the latest Soviet achievements in the field. I am sure the reader will be anxiously looking forward to its second edition.

G. A. TokatY

\section{HYLLERAAS'S PAPERS}

Selected Scientific Papers of Egil A. Hylleraas

Edited by John Midtdal, Knut Thalberg and Harald Wergeland. Vol. 1: Pp. viii +445 . Vol. 2: Pp. 526. (N'TH Press: Trondheim, 1968.) n.p.

Egir Hylleraas started research in the theory of crystal lattices and in 1926 went to work with the leader in that field, Max Born, only to find Born entirely full of the new quantum mechanics. After some persuasion, Hylleraas took to applying quantum mechanies to the helium atom and thereafter produced a brilliant stream of papers applying quantum mechanies to the problems of chemical physics. The important thing in those early days was not just that quantum mechanics produced more elegant solutions of problems the solutions of which had been obtained by the old quantum mechanics, but that really accurate new predictions could be made in really complicated situations. Hylleraas seemed designed by nature to take on these problems and with Hartree gave us the basis of quantitative atomic structure. His collected papers have been edited by three leading Norwegian physicists and provide a fascinating view of the development of this branch of physics and of the man himself. One might expect in such a volume a brief biography, but the editors have only provided a brief curriculum vitae because something far better lies among the papers-a brief autobiography. This is a delightful account of his own scientific career and vivid recollections of the Göttingen of the mid twenties, given as a speech at the University of Wisconsin and published in the Reviews of Modern Physics. The reader should turn here first to get a true perspective of the papers. I think everyone interested in the history of physics will find these papers and this commentary of great interest and will wish that all the scientists named in Hylleraas's reminiscences would likewise record their experiences, and be so handsomely treated by their colleagues.

I remember Hylleraas visiting Hartree in Cambridge a few years after the war. Needing to do some calculations, he inspected the various machines available (from digital downwards), but eventually chose the humblest Brunsviga over which he reckoned he had the greatest control. In the reminiscences he records the mental processes which went into transforming the good agreement for helium into the very good, by detecting a subtle error of principle in the analysis which weakened the numerical analysis. I suppose nowadays one would have put it all on to a great machine, but would one have learned the things Hylleraas did that way?

S. F. EDWARDS

\section{Correspondence}

\section{Digging"but not Keeping}

SIR,-This institution echoes the views expressed in your article "Digging but not Keeping" (Nature, 221, 206; 1969), though we would not wholly agree with the solution you propose to the problem. We think that the Ministry of Public Building and Works has seriously neglected its responsibilities to provide an efficient laboratory for the Inspectorate of Ancient Monuments.

This inspectorate is held in high regard throughout the world and it has done everything possible to establish a laboratory capable of meeting the requirements of British archaeology. There is little doubt that its efforts have been impeded by bureaucracy. In October 1965 proposals were put by MPBW to this institution on new staffing arrangements for the laboratory to meet the increasing work load. There was to be a Chief Laboratory Officer supported by eleven staff in the Experimental Officer and Conservation Officer Classes. Months later-in mid-1966 - Mr J. W. G. Musty was appointed as head of the laboratory.

Because of lack of progress in reorganizing and staffing the laboratory, the institution persuaded MPBW jointly to carry out an inspection. The institution's representative reported, "The laboratory had a backlog of about eight years' work and though young people had been recruited and had received training they had left for more remunerative work in provincial museums. We came away with the impression that although the laboratory was well equipped, and the work waiting to be done, there was no one there to do it."

Still the situation did not improve. In December 1967 we made further representations to the ministry. We said, "We have now had some experience of the reorganized laboratory introduced by the Department and there are a number of points on which we are not at all happy. First, the Department's proposal to 'plan a well coordinated laboratory' seems to have run completely on the rocks. The two sections of the laboratory are housed in different buildings and I am informed that the extent to which there is coordination is not very real. One would have thought that the first stage in producing coordination would have been to ensure the creation of one laboratory under one roof so that the officer in charge would be wholly responsible for its day to day work. Instead, we find two quite separate laboratories-each of which seems to be quite separate and distinct from the other.

"Of more immediate concern to the institution is the way in which the complement you proposed in 1965 has not yet come into being."

These representations resulted in the ministry conducting an O. \& M. survey of the laboratory in September 1968. The agreed terms of reference were: (1) to review the functions, organization and scope of work being undertaken by the Sections of the Ancient Monuments Laboratory under the Chief Laboratory Officer, particularly in the light of the Treasury Inspection Report of 7th May, 1965; (2) to examine the relationship between the Ancient Monuments Laboratory and those agencies having facilities to assist it (e.g. the British Museum, other museums, universities and learned bodies); (3) to consider the scope and range of functions which should be undertaken by the laboratory, and to recommend an appropriate organization and complement for the work load falling upon it or likely to fall upon it.

The wheels of Whitehall grind exceedingly slow and we still await the report of the survey. Though you suggest that the laboratory should be subjected to a Fulton 
"hiving-off" operation, we think the ministry should first exercise some "accountable management" as proposed by Fulton. It is only too clear to us that they have ignored the needs of the inspectorate and British archaeology.

$$
\text { Yours faithfully, }
$$

The Institution of Professional

\section{T. H. Profity}

Civil Servants,

Northumberland Street,

London WC2.

\section{Synthetic Foodstuffs}

SIr,--I wish to clarify the reference to the work of the Tropical Products Institute in the summary of the Parliamentary Question which appeared in your issue of Decomber $28(220,1271 ; 1968)$.

This institute is not, in fact, currently carrying out any work on novel marine sources of proteins. However, one of our projects (Tropical Products Institute, Annual Report 1967) does concern East African freshwater fish and involves study of means of preservation and improvement of quality.

Yours faithfully,

\section{P. C. Spensley}

'Tropical Products Institute,

56-62 Gray's Inn Road,

London WC1.

\section{Probability and Prejudice}

SIR,--Professor Lindley (Nature, 221, 594; 1969) is, like Matthew, entitled to his opinion, but I do not see that his comments in any way dispose of my criticisms. First of all, perhaps I could protest at the irrelevant remarks in his first paragraph, which includes an inaccurate reporting of what I quoted Professor Maynard Smith as saying, namely, that the problem "yields at once to common sense or to Bayes's theorem". By omitting the phrase "to common sense or" Professor Lindley distorts, quite unfairly, the implication in my own remarks.

To come now to the problem, this is unsatisfactory partly because of the third-person reporting in it of Matthew's opinions as data to be used in any numerical evaluations. These data included Matthew's assessments of his own probability of execution as changing from $2 / 3$ to $1 / 2$, so that he had a right to feel happier, in particular if it could be shown that he was being consistent. Professors Maynard Smith and Lindley apparently think he had no such right, but my claim that this view "may legitimately be questioned" was illustrated by my demonstrating how Matthew could be consistent in his assessments. Lindley introduces the further assumption that $r=1 / 3$ "as a reasonable value", and concludes that $P$, the probability of the jailer naming Mark if both Mark and Luke are to be executed, would then have to be $I$. Dismissing this possibility, Lindley rejects the consistency of Matthew's assessments. Even if I accept Lindley's value $r=1 / 3$ (which Matthew may not have done), Matthew has, however, still a "right to fecl happier" on the weaker basis that his second assessment should be at any rate $<2 / 3$, which leads to the condition $P>1 / 2$. I sec nothing extraordinary in such a bolief by Matthew about $P$, especially if he recalls the order of precedence of Mark and Luke in the New Testament. (The jailer may not be a Christian, but Matthew may bo unaware of this.)

\section{Yours sincerely,}

Department of Biomathematics,

M. S. BartletT

Pusey Street,

Oxford.

\section{Mr Short's Shibboleth}

SIR,-Your editorial "Mr Short's Shibboleth" (Nature, 221,298 ; 1969) criticizing arrangements to teach religion in schools is in part based on the relevance of the old Testament to contemporary situations. The useful supplement to this docurnent which was later issued has a more up-to-date approach.

Yours faithfully, PAtrick Fallon

4 Worcester Road, London SW 19.

\section{University News}

Dr F. P. Lisowaki, University of Birmingham, has been appointed professor of anatomy at the University of Hong Kong.

Dr A. Donnachie, University of Glasgow, has been appointed to an additional chair of theoretical physics at the University of Manchester.

\section{Announcements}

Sir Alexander Haddow is to retire on March 31 from his directorship of the Chester Beatty Research Institute. $\mathrm{He}$ will continue his researches as professor of experimental pathology.

The Scientific Medal, awarded by the Zoological Society of London, has been won by Dr G. A. Horridge, director of the Gatty Marine Laboratory, University of St Andrews, in recognition of his work in zoology; a second Scientific Medal has been awarded to Dr M. Wells of the University of Cambridge. The Glough Award of the Edinburgh Geological Society has been awarded to Dr M. J. O'Hara, Grant Institute of Geology, University of Edinburgh, in recognition of his mineralogical and petrological studies in the rocks of the Scottish Highlands.

The Macromolecular Research Centre has recently been established at the University of Michigan. Its objec. tives are to provide intensive graduate and postdoctoral research and education training in the field of macromolecular science, with emphasis on chemical and physical studies of natural and synthetic macromolecules.

Erratum. In the article "Stomatal Closure and Inhibition of Transpiration induced by (RS)-Abscisic Acid" by Cathryn J. Mittelheuser and R. F. M. Van Steveninck (Nature, 221, 281; 1969) the contents title unfortunately contradicted the authors' findings. It should have read "Abscisic acid induces stomatal closure and inhibits transpiration".

Erratum. In the introductory paragraph to the article "Structure-Activity Relationships of One-Ring Psychotomimetics" by Alexander T. Shulgin, Thornton Sargent and Claudio Naranjo (Nature, 221, 537; 1969) "triple methoxy substitution" should have read "trisubstitution". In Table 3 "Potential for ortho-quinone only; oxygen available" should have read "Potential for ortho-quinone only; oxygen not available". On p. 540, twenty-three lines down (XXIV, MU = I) should have read (XXIV, $\mathrm{MU}<1$ ).

ERratum. In the article "Bark Beetle Attractants: Identification, Synthesis and Field Bioassay of a New Compound isolated from Dendroctonus" by G. W. Kinzer et al. (Nature, 221, 477; 1969) the first sentence of the fifth paragraph should read "The activity of the synthesized compound was tested in field conditions in the Boyce 'Thompson Institute's experimental forest near Beaumont, Texas, using tree trunk simulating olfactometers ${ }^{8}$ ". 